九州大学学術情報リポジトリ

Kyushu University Institutional Repository

\title{
Reexamination of the Brachiopod Fauna from the Permian Karita Formation, Southwest Japan
}

Yanagida, Juichi

Faculty of Science, Kyushu University

Imamura, Sotoj i

Hiroshima University : Professor Emeritus

Kawai, Mayumi

https://doi.org/10.5109/1543641

出版情報 : 九州大学大学院理学研究院紀要 : Series D, Earth and planetary sciences. 28 (1)，pp.121, 1993-12-25. Faculty of Science, Kyushu University

バージョン :

権利関係 : 
Mem. Fac. Sci., Kyushu Univ., Ser. D, Earth Planet. Sci., Vol. XXVIII, No. 1, pp. 1-21, pls. 1-2, text-figs. 1-8, Dec. 25, 1993

\title{
Reexamination of the Brachiopod Fauna from the Permian Karita Formation, Southwest Japan
}

\author{
Juichi YANAGIDA \\ Sotoji IMAMURA* and Mayumi KAWAI**
}

\begin{abstract}
Permian brachiopods from the Karita Formation in the Inner Zone of Southwest Japan, first introduced and discussed by the junior author IMAMURA (1953), are herein reexamined and systematically described. Several new materials of brachiopods, collected and briefly examined by KAWAI (HASE and AIBA, 1977), have been added for the study. The brachiopod fauna is composed of 10 species among 9 genera. Two indeterminable genera belonging to Strophalosiidae are also discriminated. The faunal elements are closely comparable with those of the Upper Permian Takauchi Limestone of the Permian Maizuru Group, Southwest Japan (Shimizu, 1961) and are also closely related to those of the Upper Permian Lontangian fauna (LIAO, 1980) of South China.

Key words: Upper Permian brachiopods, Codonofusiella Zone, Karita Formation, Southwest Japan
\end{abstract}

\section{Introduction}

One of the present authors, IMAMURA, reported the occurrence of a "Lyttonia fauna" in 1953 from the Permian Karita Formation distributed in about $30 \mathrm{~km} \mathrm{NE}$ of Hiroshima City. Another present author, KAWAI, clarified the stratigraphy of the Karita Formation in 1977 with HASE. Their detailed discussion on biostratigraphy of the Karita Formation is based on fusulines and the smaller foraminifers described and discussed by OKIMURA and SADA as a palaeontological note in the preceding paper by HASE and AIBA (1977). Of them some fusuline fossils represented by Lepidolina toriyamai KANMERA were discriminated from the Member $\mathrm{c}$ of the Karita Formation. The overlying thick beds of the Member $d$ are mainly composed of slates and occasionally small lenses of limestone of about $5 \mathrm{~m}$ 's thick. These limestone lenses well comprise fusulines and the smaller foraminifers and 15 species among 13 genera, including Colaniella cf. minima WANG, Nodosaria mirabilis K.M.-MAKLAY, Globivalvulina sp., Reichelina sp. and Codonofusiella sp., were discriminated by OKIMURA and SADA.

The "Lyttonia fauna" by IMAMURA (1953) and the newly collected brachiopods by KAWAI (HASE and AIBA, 1977) occur from a calcareous sandstone and small limestone of the Member $d$ at a horizon just above the limestone lens of Loc. 6 (See Fig. 2).

\footnotetext{
* Professor Emeritus of Hiroshima University

** 2-2-4 Tsuda-cho, Kodaira-shi, Tokyo (formerly M. AIBA)

Manuscript received November 1, 1993.
} 


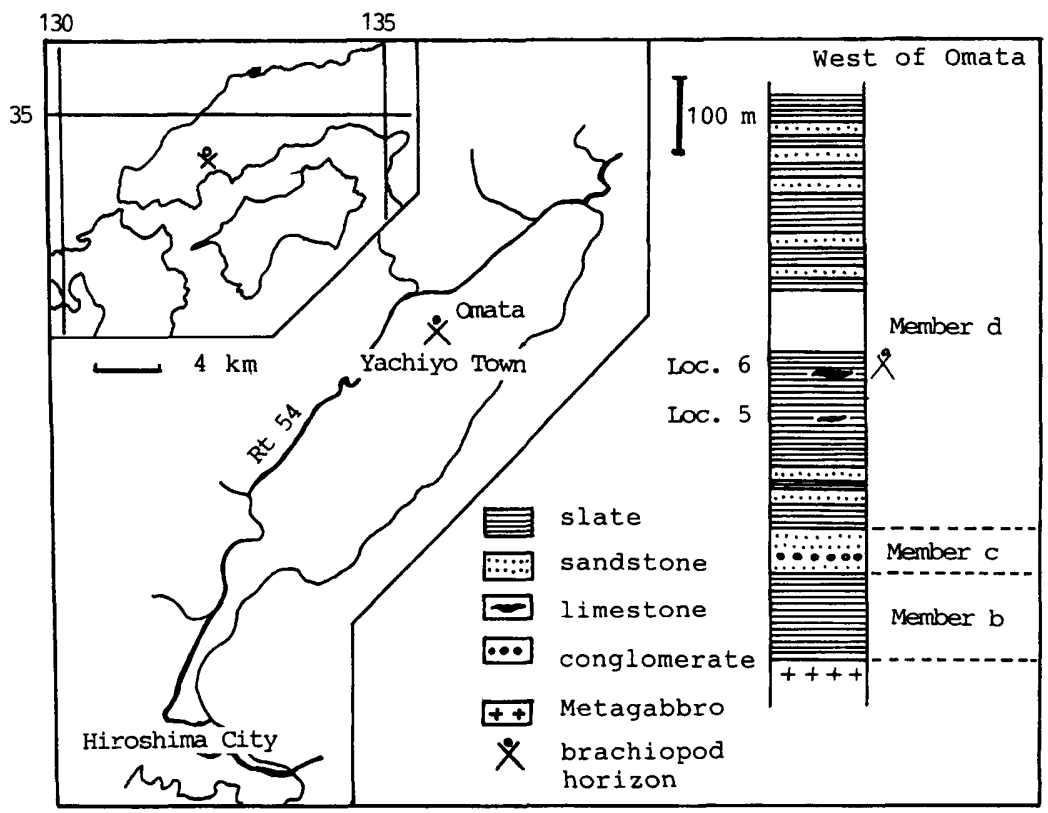

Fig. 1. Index map briefly showing the locality of brachiopods and a columnar section of a part of the Karita Formation with the stratigraphic horizon of the described specimens (After HASE and AIBA, 1977).

Imamura reported the following brachiopod species; Leptodus richthofeni KAYSER, Chonetes sp., Productus sp., Camarophoria sp., Spiriferellina aff. cristata SCHLOTHEIM, Schellwienella cf. rubber (FRECH), S. aff. acutangulata HuANG, Hustedia cf. grandicosta lata GRABAU. IMAMURA remarked co-occurrence of such molluscan fossils as Pseudoamussium sp., Bellerophon sp. and Dentalium sp..

As the result of reexamination of the preceding brachiopods from the Karita Formation, the following faunal elements have been discriminated; Oldhamina anshunensis HuANG, Leptodus sp., Neochonetes substrophomenoides, Derbyia cf. altestriata WAAGEN, Derbyia sp, Strophalosiidae gen. et sp. indet. A, Strophalosiidae gen. et sp. indet. B, Echinosteges ? sp., Allorhynchus sp., Hustedia sp., Spiriferella sp., Spiriferellina sp..

Repository: All brachiopod specimens treated in this paper are kept in the Department of Earth and Planetary Systems Science, Faculty of Science, Hiroshima University, with the designation of $\mathrm{HSG}-(\mathrm{H})$ for the registered number of the specimens.

Acknowledgements: We express our sincere thanks to Professor Yuji OKIMURA of Hiroshima University who kindly gave us the opportunity of examining brachiopod specimens of the Karita Formation and gave us valuable opinions. Our sincere thanks are also due to Professor Kimiyoshi SADA of Hiroshima University for his continuous encouragement. Financial support for the present study was provided by the Ministry of Education, Science and Culture, Japanese Government. 


\author{
Systematic description \\ Superfamily Lyttoniacea WAAGEN, 1883 \\ Family Lyttoniidae WAAGEN, 1883 \\ Genus Oldhamina WAAGEN, 1883 \\ Type species.-Bellerophon decipiens DE KONINCK, 1863 \\ Oldhamina anshunensis HUANG \\ Pl. 1, figs. 7, 10
}

1932. Oldhamina squamosa var. anshunensis Huang. Palaeont. Sinica, vol. 9, fasc. 1, p.

77 , pl. 6 , figs. $1-4$.

1978. Oldhamina anshunensis, FENG and JIANG. Brachiopoda in Fossil atlas of southwest province, Guizhou part 2. Science Press, Beijing, p. 271, pl. 101, fig. 23.

1980. Oldhamina anshunensis, LiAo. In Stratigraphy and palaeontology of Upper Permian coal-bearing formation in western Guizhou and eastern Yunnan. Nanjing Inst. Geol. Paleont., Acad. Sinica, Sci. Press, Beijing, pl. 5, fig. 49.

1982. Oldhamina squamosa var. anshunensis, LIU, TAN, and DING. Brachiopoda in The palaeontological atlas of Hunan. Geol. Mem., ser. 2, no. 1, Geological Publishing House, Beijing, p. 190, pl. 136, fig. 13.

1982. Oldhamina squamosa var. anshunensis, WANG et al. Brachiopoda in Palaeontological atlas of east China, Section 2. Nanjing Inst. Geol. Mineral Resources, Acad. Sinica, Geological Publishing House, Beijing, p. 230, pl. 91, fig. 18.

1983. Oldhamina anshunensis, ZHAN, FUL, DING and QI. Brachiopoda in Palaeontological atlas of northwest China, Shanxi, Gansu and Ningxia volume, Part 2. Xian Inst. Geol. Mineral Resources, Geological Publishing House, Beijing, p. 297, pl. 102, figs. $5,6$.

Material.-Two incomplete internal moulds of pedicle valve, HSG-(H) 001 and 002, are available. Of them the latter one represents the posterior part and probably it reveals a young stage of growth.
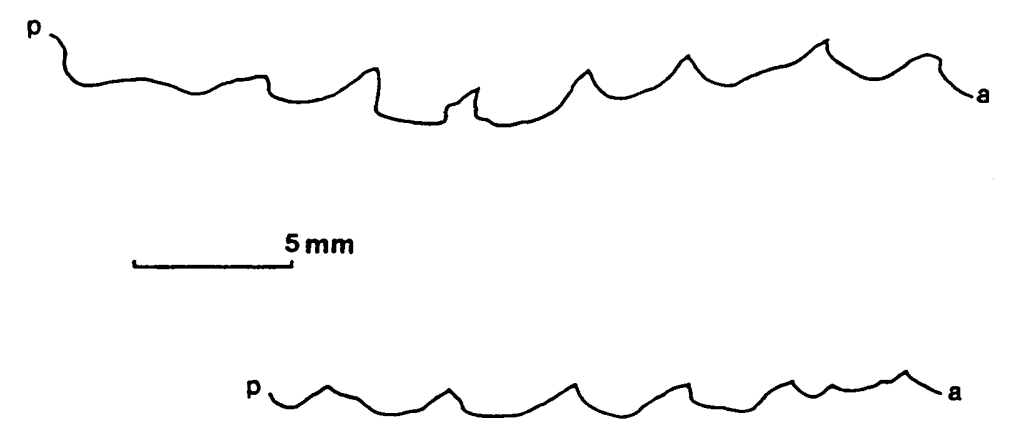

Fig. 2. Oldhamina anshunensis HUang. Profiles of two longitudinal sections of a pedicle valve, HSG-(H) 001, showing lateral septa in a development of anguliseptate state. a, anterior; $p$, posterior 
Description.-The shell is moderate in size, transversely and irregularly oval in outline with the anterior half more transverse than the posterior one, and is slightly longer than wide. The pedicle valve is slightly convex and weaker in convexity in the longitudinal proflle than the transverse one. The posterior half of the valve is transversely more convex than the anterior one with rather steep flanks near the postero-lateral margin of valve. Interior of the pedicle valve is characterized by pairs of lateral septa, arranged in row on each side of the median ridge. Their crests are very sharp and thin, showing an anguliseptate state of development. They are counted 13 at least, tilted anteriorly with gentle posterior and steep anterior slopes, and convexly disposed toward the anterior direction with an angle of about 85 degrees to median ridge. Very fine, longitudinally short striae, about 6 to 7 in a distance of 5 $\mathrm{mm}$, are occasionally visible on the posterior surface near the crest of lateral septa. Median part of the valve is with very low, discontinuous median ridge, normally obsolete in the anterior half, but it becomes distinct posteriorly.

The largest specimen at our disposal has the following dimension; $55 \mathrm{~mm}$ wide, more than $41 \mathrm{~mm}$ long, $19.1 \mathrm{~mm}$ high, and about $3.5 \mathrm{~mm}$ distant between crests of the lateral septa.

Remarks.-The characters of the present specimens are well in harmony with those of Oldhamina squamosa var. anshunensis from the Upper Permian coalbearing formation of Chiaotzushan, Guizhou by Huang (1932). This was treated as a full species by FENG and JIANG (1978) on the basis of its wide geographic distribution in south China, constant stratigraphic occurrence, and its distinctive character from others. FENG and JIANG (1978) refigured the holotype designated by HUANG and noted in their explanation of plate that it came from the Upper Permian Changsing Formation in Anshun, Guizhou. LIAO (1980) discussed the Upper Permian brachiopod fauna from the coal-bearing formation in Western Guizhou. According to his Table 1, Oldhamina anshunensis is known from the Lontang Stage of the Upper Permian of Chiaotzunshan of Anshunsien, Guizhou. Anyhow LIAO summarized the occurrence of O. anshunensis HUANG, ranging from the Lontangian up to Changsingian Stages in the Upper Permian in western Guizhou and eastern Yunnan.

Outside of south China $O$. anshunensis is known from some regions of Upper Permian such as the Lontangian Stage in Anhui, eastern China (WANG et al., 1982), Pukou of Jing-xian in southern Hunan (LIN, TAN, and DING, 1982) and the Xikou and Longdongchuan Formations in Xikou, Shaanxi, northwestern China (DING and QI, 1983).

Oldhamina jiaozishanensis LIAO (1980) from the Upper Permian of the Lontangian Stage in Jiaozishan of Anshun, Guizhou, seems to be very close to $O$. anshunensis.

TAZAWA (1982) described Oldhamina kitakamiensis from the Upper Permian Toyoma Formation in Kanayashiki, southern Kitakami Mountains and remarked $O$. anshunensis as a close alliance to $O$. kitakamiensis. Although the kitakami material is very poorly preserved and then it is difficult to compare the detailed character of the former with that of the latter, the size, relative number of lateral septa to the length of valve and the weak convexity of the pedicle valve of both species are very similar with each other. The slight difference between the Kitakami and the present species is recognizable on the lateral septa of which the present species are anteriorly more convex than the former in their shape. 
Genus Leptodus KAYSER, 1882

Type-species.—Leptodus richthofeni KAYSER, 1882

Leptodus sp.

Pl. 1, figs. 8, 9

Descriptive remarks.-Two incomplete specimens, a large but fragmentary brachial valve (HSG-(H) 003) and a fragmentary mould of pedicle valve interior (HSG-(H) 004) are available. The external configurations of them strongly suggest a largely triangular outline of shell with weakly convex and slightly distorted pedicle valve. Entire length of the shell is not confirmed. The pedicle valve interior is with the erect lateral septa in solidiseptate state of development, counted about four in $10 \mathrm{~mm}$ and totally twelve septa on each side of the median low and discontinuous ridge. The brachial valve is minutely granulated externally. The lateral lobes on each side of the internal plate are anteriorly weakly convex, making high angles to the internal plate.

The posteriorly tapering form of the shell and arrangement of the lobes of the present specimens strongly recall characters of Leptodus richthofeni KAYSER. On the other hand the fragmentary state of preservation and their present sizes give us possibility of having a large size and numerous number of lobes in the complete shell. If so then they will reveal the character of Leptodus nobilis (WAAGEN). As far as the present specimens are concerned, they are closely related to those of south Chinese and Pakistan Upper Permian representative species, respectively.

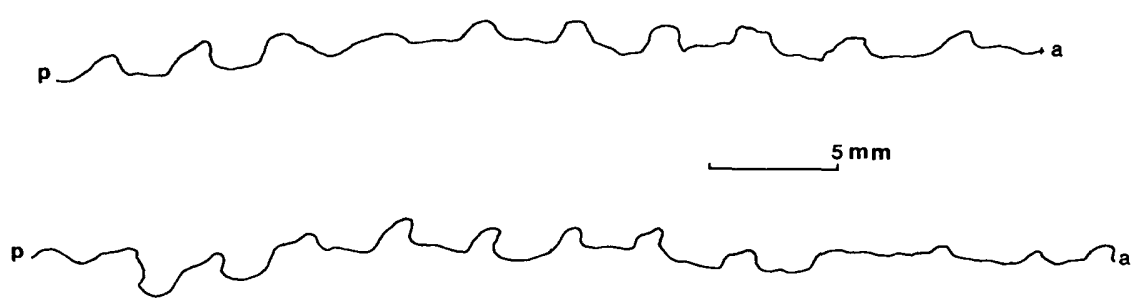

Fig. 3. Leptodus sp. Profiles of two longitudinal sections of a pedicle valve, HSG-(H)004, showing the lateral septa in a development of solidiseptate state. a, anterior; $p$, posterior

Superfamily Chonetacea BRONN, 1862

Family Rugosochonetidae MUIR-WOOD, 1962

Subfamily Rugosochonetinae MUIR-WooD, 1962

Genus Neochonetes MUIR-Wood, 1962

Type-species.-Chonetes dominus R. H. KING, 1938

Neochonetes substrophomenoides (HUANG)

Pl. 2, figs. 2-9

1932. Chonetes substrophomenoides Huang. Palaeontologia Sinica, vol. 9, fasc. 1, p. 3, pl.

1, figs. 3-7.

1961. Chonetina substrophomenoides, Shimizu. Mem. Coll. Sci., Univ. Kyoto, ser. B, vol. 28 , no. 3, p. 317 , pl. 16, figs. 11-17.

1961. Chonetina cf. strophomenoides, ShImızu. Ibid., pl. 16, figs. 7-10. 
Material:-Densely crowded moulds of both valves are available. The external and internal characters are well examined by making their rubber replicas. Of them six brachial and five pedicle valves are better preserved specimens.

Description:-The shell is small, slightly trapezoidal, with the widest part at the hinge line or slightly anterior to it. The pedicle valve is slightly convex with the anteriorly broad and round-bottomed sulcus. Bilobation of the pedicle valve is weakly developed. The beak is not well preserved, but suggested to be slightly projected.
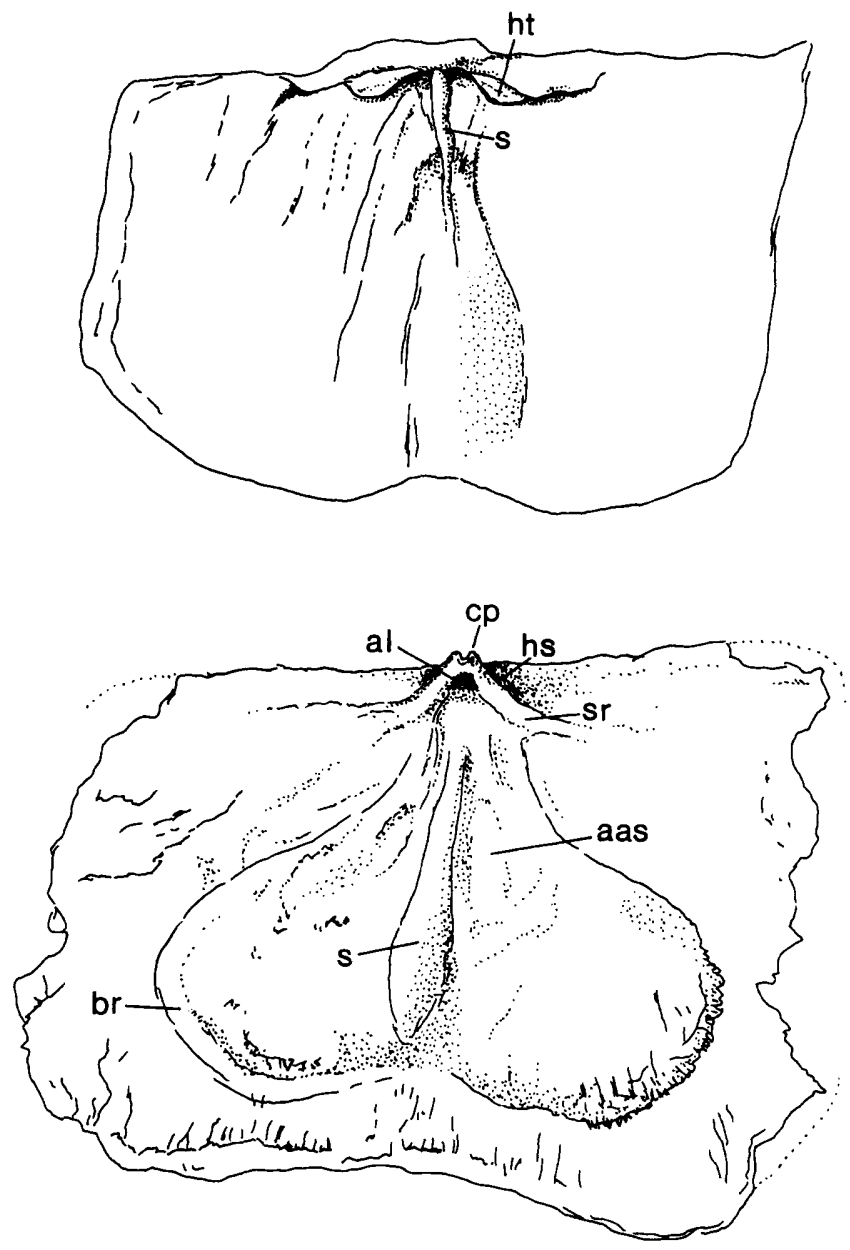

\section{$5 \mathrm{~mm}$}

Fig. 4. Neochonetes substrophomenoides (HUANG). Rubber replicas, showing the pedicle valve interior (upper, HSG(H)030) and the brachial valve interior (lower, HSG-(H)031), respectively.

aas, anterior adductor scars; al, alveolus; br, brachial ridges; $\mathrm{cp}$, cardinal process; hs, hinge sockets; ht, hinge teeth; s, septum; sr, socket ridges 
Measurements (mm)

\begin{tabular}{|c|c|c|c|c|}
\hline specimens & length & $\begin{array}{l}\text { length of } \\
\text { hinge line }\end{array}$ & midwidth & $\begin{array}{l}\text { width of fold } \\
\text { or sulcus at } \\
\text { anterior margin }\end{array}$ \\
\hline $\left.\begin{array}{l}\text { pedicle valve } \\
\text { (HSG-(H)005) }\end{array}\right]$ & 8.5 & $10+$ & ca. 10 & ca. 5 \\
\hline $\left.\begin{array}{l}\text { pedicle valve } \\
(\text { HSG-(H)006) }\end{array}\right]$ & 7.1 & 8.7 & 7.9 & ca. 4 \\
\hline $\left.\begin{array}{l}\text { pedicle valve } \\
\text { interior } \\
(\mathrm{HSG}-(\mathrm{H}) 007)\end{array}\right]$ & 5.9 & $8.5+$ & 8.5 & ca.4 \\
\hline $\left.\begin{array}{l}\text { pedicle valve } \\
\text { interior } \\
\text { (HSG-(H)008 }\end{array}\right]$ & 6.7 & 8.4 & 7.8 & ca. 3 \\
\hline $\left.\begin{array}{l}\text { pedicle valve } \\
\text { interior } \\
(\mathrm{HSG}-(\mathrm{H}) 009)\end{array}\right]$ & 4.1 & ca. 6 & ca. 6 & 1.3 \\
\hline $\left.\begin{array}{l}\text { brachial valve } \\
(\mathrm{HSG}-(\mathrm{H}) 010)\end{array}\right]$ & 8.1 & $12+$ & $10+$ & ca. 5 \\
\hline $\left.\begin{array}{l}\text { brachial valve } \\
\text { (HSG-(H)011 }\end{array}\right]$ & ca. 8 & $10+$ & ca. 9 & ca. 4 \\
\hline $\left.\begin{array}{l}\text { brachial valve } \\
\text { interior } \\
\text { (HSG-(H)012) }\end{array}\right]$ & 8.8 & $9+$ & 11.2 & \\
\hline $\left.\begin{array}{l}\text { brachial valve } \\
\text { interior } \\
\text { (HSG-(H)013) }\end{array}\right]$ & 7.7 & $8+$ & 9.8 & \\
\hline $\left.\begin{array}{l}\text { brachial valve } \\
\text { interior } \\
\text { (HSG-(H)014) }\end{array}\right]$ & 8.3 & $10+$ & 11.6 & \\
\hline $\left.\begin{array}{l}\text { brachial valve } \\
\text { interior } \\
\text { (HSG-(H)015) }\end{array}\right]$ & 7.2 & ca.11 & 10.7 & \\
\hline
\end{tabular}

The brachial valve is weakly concave with the slightly convex, anteriorly widened, low fold. The both valves are finely capillate.

The pedicle valve interior has broad teeth, long median septum, anteriorly attaining at a distance slightly longer than a half of the shell length. Occasionally the longitudinal thickenings parallel to median septum are recognizable in some specimens. The brachial valve interior has laterally elongated sockets with the socket ridges parallel to the hinge line. The lateral septa are short. The cardinal process is small and ventrally bilobate with distinct alveolus anterior to it. The median septum originates at anterior to the alveolus as a low ridge, rapidly increasing in height and width anteriorly and extends to a distance slightly more than a half of the valve 
length. The brachial ridges are remarkably disposed, making a couple of platform. The endospines are numerously scattered antero-laterally.

Remarks.-As far as the external characters are concerned the present specimens are identical with those of Neochonetes substrophomenoides (HUANG) from the Upper Permian Lyttonia bed in Guizhou, south China. Sometimes this species was reported in China under the generic name of Chonetinella. The small size and weakly bilobated character of the pedicle valve remind us the character of Chonetinella. However, the present species has the fine capillae, about 3 capillae in $1 \mathrm{~mm}$ near the anterior margin, and also wide and shallow sulcus in the pedicle valve. HUANG did not describe the internal characters of the brachial valve. The present specimens well reveal the characters of Neochonetes, such as the thickened character of the antero-lateral part of the visceral area and the anteriorly elevated median septum.

SHIMIZU (1961) described seven chonetacean species from the Upper Permian Maizuru Group. Of his figured specimens among three forms of Chonetina substrophomenoides (HUANG), those of form B group seem to be very close to the present specimens in the size and external characters. The present species may be one of the smallest species of Neochonetes.

\section{Explanation of Plate 1}

Fig. 1. Hustedia sp. page 17

1a, b. Rubber replicas, respectively showing the exterior and the internal mould of a brachial valve, HSG- $(\mathrm{H}) 023, \times 3$.

Fig. 2. Spiriferell sp. page 18

A posteriorly broken pedicle valve, $\mathrm{HSG}-(\mathrm{H}) 024, \times 1.5$.

Figs. 3-5. Spiriferellina sp. page 18 Incomplete pedicle valves, respectively HSG-(H)025, 026 and $027, \times 3$.

Fig. 6. Strophalosiidae gen. et sp. indet. A.................................... page 13 $6 \mathrm{a}, \mathrm{b}$. Rubber replicas, respectively showing the dorsal and ventral views of a brachial valve interior, HSG-(H)028, with dendritic pads of the inflated adductor muscle fields, deep sockets, and the strong cardinal process, $\times 3$.

Figs. 7, 10. Oldhamina anshunensis HuANG. page 3

7. A rubber replica of the posterior part of an incomplete pedicle valve, showing anteriorly inclined lateral septa in anguliseptate state of development, HSG(H)002, $\times 1$.

$10 \mathrm{a}, \mathrm{b}$. Respectively internal mould of pedicle valve and the rubber replica, showing anteriorly inclined anguliseptate septa, HSG-(H)001, $\times 1$.

Figs. 8, 9. Leptodus sp. page 5

8. A rubber replica of an incomplete pedicle valve, showing erect lateral septa in solidiseptate state, HSG-(H)004, $\times 1$.

$9 \mathrm{a}, \mathrm{b}$. Respectively granulated outer surface of an incomplete brachial valve and its external mould, respectively, HSG-(H)003, $\times 1$. 
Mem. Fac. Sci., Kyushu Univ., Ser. D, XXVIII
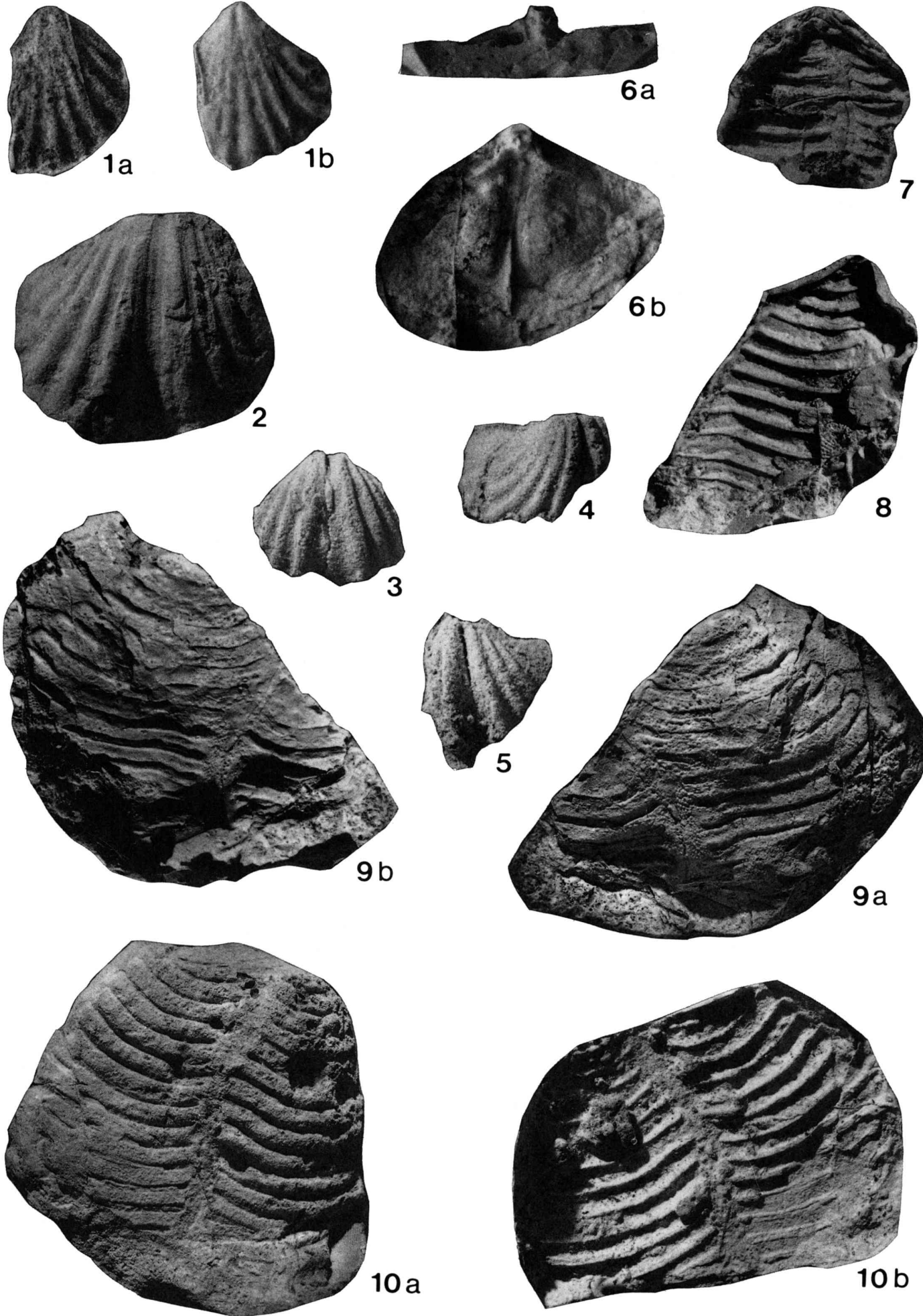

J. Yanagida, S. Imamura \& M. KawaI: Brachiopods from Karita 
Mem. Fac. Sci., Kyushu Univ., Ser. D, XXVIII

Plate 2

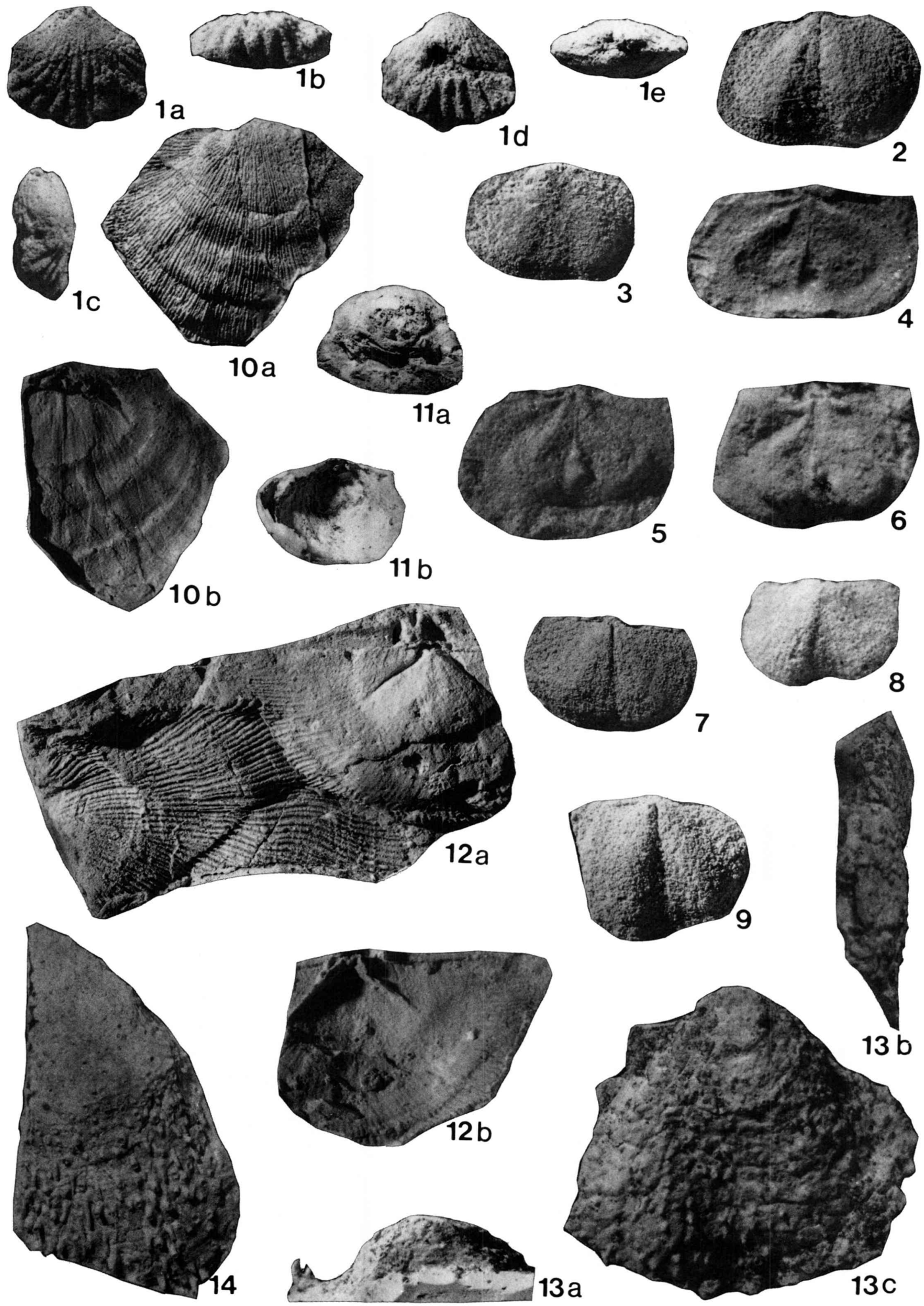

J. YANAGIDA, S. ImAmuRA \& M. KAWAI: Brachiopods from Karita 


\author{
Superfamily Davidsoniacea KING, 1850 \\ Family Derbyiidae STEHLI, 1954 \\ Subfamily Derbyiinae STEHLI, 1954 \\ Genus Derbyia WAagen, 1884 \\ Type-species._Derbyia regularis WAAGEN, 1884 \\ Derbyia cf. altestriata (WAAGEN)
}

Pl. 2, fig. 10

1882. Derbyia altestriata WaAgen. Palaeontologia Indica, ser. 13, Salt Range fossils, p. 600 , fig. 2.

1961. Derbyia altestriata, Shimizu. Mem. Coll., Univ. Kyoto, ser. B, vol. 27, no. 3, p. 314 , pl. 15, figs. 1,2 .

Descriptive remarks.-The external and internal moulds of a fragmentary brachial valve, HSG-(H)016, are available. Complete outline is not confirmed but rather regularly arranged growth wrinkles well suggest the transversely subrounded outline of the shell. The shell is small for the genus. The widest part locates at about

\title{
Explanation of Plate 2
}

Fig. 1. Allorhynchus sp. page 16 1a-e. A small incomplete shell, HSG-(H)022, respectively showing dorsal, anterior, lateral, ventral and posterior views, $\times 3.5$.

Figs. 2-9. Neochonetes substrophomenoides (HUANG). page 5 2,7 , 9. Internal moulds of pedicle valve, respectively HSG-(H)005, 008 and 017 , $\times 3$.

3 , 8. Pedicle valves, respectively $\mathrm{HSG}-(\mathrm{H}) 006$ and $028, \times 3$.

4, 5, 6. Rubber replicas of brachial valve interiors, HSG-(H)014, 012 and 013, respectively, $\times 3$.

Fig. 10. Derbyia cf. altestriata (WAAGEN). page 11 $10 \mathrm{a}, \mathrm{b}$. Rubber replicas of the outer and inner surfaces of a brachial valve, respectively showing the external ornamentation and incomplete cardinal process, HSG-(H)016, $\times 1$.

Fig. 11. Strophalosiidae gen. et sp. indet. B.

page 14

$11 a, b$. Posterior view of an internal mould of a pedicle valve and the rubber replica, respectively, showing a pair of long hinge teeth, HSG-(H)019, $\times 1$.

Fig. 12. Derbyia sp. page 12 12a, b. Respectively internal moulds of a brachial valve with a posterior part of pedicle valve, and a rubber replica of the preceding brachial valve, showing the cardinal process, HSG-(H)018, $\times 1.5$.

Figs. 13, 14. Echinosteges? sp. page 14 $13 \mathrm{a}, \mathrm{b}, \mathrm{c}$. Posterior, lateral and ventral views of a rubber replica of a pedicle valve, respectively, showing dense arrangement of short irregularly developed spines, HSG-(H)020, $\times 3$.

14. A rubber replica of a fragmentary pedicle valve, showing suberect and prostrate spines, HSG-(H)021, $\times 2$. 
midlength or slightly anterior to it. The brachial valve is weakly and uniformly convex with the largest convexity at the umbonal region. The surface is covered by the fine rounded costellae, about 9 costellae are observed in $5 \mathrm{~mm}$ in the anterior part with numerous intercalations. The growth wrinkles are broad and rather regularly marked, 4 wrinkles in a distance of $3.5 \mathrm{~cm}$ from break. The cardinal process is short and ill preserved but shows the bifid structure at the tip with suggestion of slits at the free end, and is supported by a pair of antero-laterlly divergent socket plates.

Internal characters of the brachial valve of the present specimen well reveal those of Derbyia. Of the external characters, those of the transversely subrounded form recognized from the concentric, regularly arranged wrinkles, and densely capillated ornament are strongly comparable to those of Derbyia altestriata WAAGEN from the Upper Productus Limestone of the Salt Range. D. altestriata was also described in Japan (SHIMIZU, 1961) from a calcareous silty shale lens in black shales of the Permian Maizuru Group in the Kawahigashi district, the Maizuru, zone, Southwest Japan. Derbyia disalata described from the Upper Permian Lontangian of Anshun, Guizhou, is distinguishable from the present species by its smaller size and less remarkable growth wrinkles.

\section{Derbyia sp.}

Pl. 2, fig. 12

Descriptive remarks.-An internal mould of brachial valve, $\mathrm{HSG}-(\mathrm{H}) 018$, is available with following dimension: width, $43 \mathrm{~mm}$; length, $20 \mathrm{~mm}$. The shell is small for the genus. The brachial valve is trapezoidal in outline and anteriorly more convex

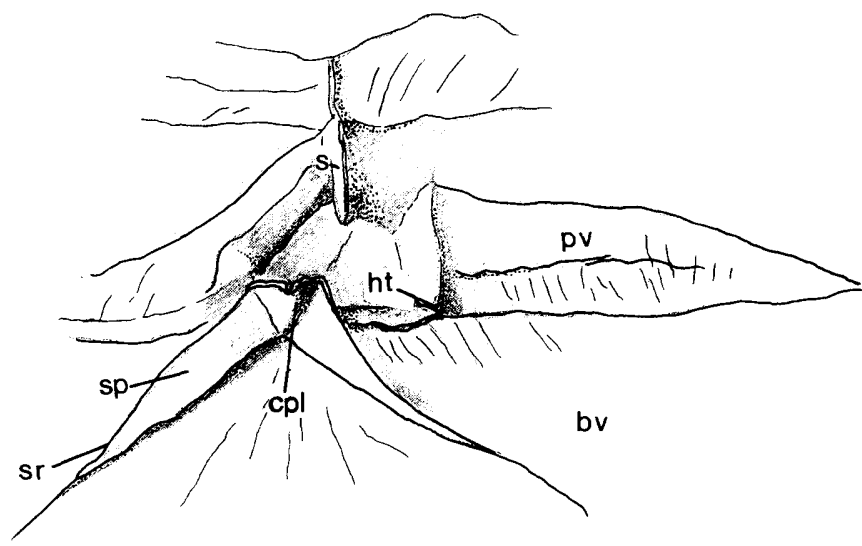

$5 \mathrm{~mm}$

Fig. 5. Derbyia sp. Internal view of a partly broken posterior part of both valves, HSG-(H)018, showing high cardinal process and others.

bv, brachial valve; cpl, cardinal process lobe; ht, hinge teeth; pv, pedicle valve; s, septum; sp, socket plate; sr, socket ridge 
than in the posterior half. The widest part locates at the hinge with laterally extended cardinal margins. A part of the low interarea of the pedicle valve, teeth, teeth ridges, and median septum are recognizable by a rubber replica. The surface is covered by the costellae, about 8 to 9 in $5 \mathrm{~mm}$ near the anterior margin. The brachial valve interior has the low cardinal process, with slightly bifid free end, supported by a pair of antero-laterally developed socket plates with divergent angle of about 100 degrees.

Although the available material is a fragmentary internal mould of brachial valve, it reveals the laterally extended character of the cardinal extremities. Taking the trapezoidal outline with the extended cardinal extremities into consideration, very close species in form are referable to two Lontangian species of Derbyia. One is $D$. acutangula (HUANG), 1933, and the other is Derbyia mucronata LIAO, 1980. Both species are the representative lower Upper Permian Lontangian ones in south China, characterized by their extended cardinal extremities. The latter species has more strongly projected extremities than the former. However, if the cardinal extremities are not well preserved, it is rather difficult to determine the specific position. The present species may be identifiable to one of the preceding species because of its trapezoidal outline.

\section{Superfamily Strophalosiacea SCHUCHERT, 1913 \\ Family Strophalosiidae SCHUCHERT, 1913 \\ Strophalosiidae gen. et sp. indet. A}

Pl. 1, fig. 6

Descriptive remarks.-An incomplete intenal mould of brachial valve, HSG(H)028, is available. The internal characters are well recognizable by a rubber replica. The brief dimension is as follows: length, ca. $11 \mathrm{~mm}$; width, ca. $15 \mathrm{~mm}$. The hinge line seems to be shorter than the maximum width which locates at slightly anterior to the midlength. The cardinal process is high, but the shape of the myophore is unknown by
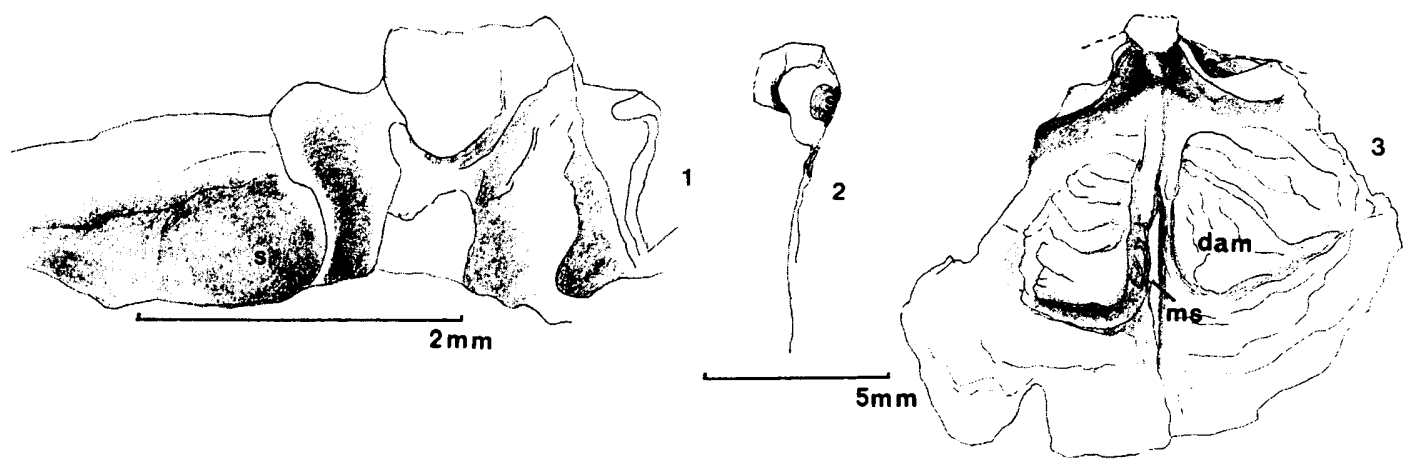

Fig. 6. Strophalosiidae gen. et sp. indet. A

1. Enlarged postero-lateral view of the cardinal process and sockets.

2. Lateral view of the cardinal process.

3. Incomplete dorsal valve interior with slightly inflated, dendritic adductor muscle fields.

dam, dendritic adductor muscle field; ms, median septum; s, socket sp. no. HSG-(H) 028 
its bad state of preservation. The lateral ridges are strong, anteriorly convex, and rapidly decreasing in height laterally. The postero-median sides of the lateral ridges make walls of deep sockets with rounded bottom. The posterior view of the cardinal process seems to be trilobed. The cardinal process is anteriorly continued by a low median septum which increases height near the anterior extremity. The adductor muscle fields are rather wide and slightly convex ventrally with the dendritic surface.

The present specimen is characterized by the deep sockets and the cardinal process which has posteriorly trilobted appearance. In these points the present specimen reveals the character of the Strophalosiidae. However, the dendritic pads of the inflated adductor muscle fields well reveal the character of the Aulostegidae. Such being the case we prefer to treat the present specimen as belonging to the Strophalosiidae until some more specimens of the brachial valve exterior and the opposite valve are obtained.

Strophalosiidae gen. et sp. indet. B

Pl. 2, fig. 11

Descriptive remarks._An incomplete mould of pedicle valve interior, HSG(H)019, is available. The following characters are confirmed by the mould and a rubber replica. The shell is smll for the family, moderately convex with the flattened venter and short trail, and tapering posteriorly with the subrounded outline. The largest convexity is at the umbonal part and the largest width at the midlength. The hinge line is very short. The anterior part shows weakly geniculated appearance. The internal surface is ornamented by the distinct growth lines or wrinkles, strongly marked on the flanks and indistinct on the trail. The radial, fine and discontinuous striae are observable on the trail. The teeth are subparallel and antero-dorsally protruded with length of about $2 \mathrm{~mm}$ or slightly less than that.

The present specimen is characteristic in having the subrounded convex form, concentric growth wrinkles or lines, and strongly projected teeth. These characters recall some genera of the Heteralosiinae. Of them, for instance, specimens belonging to Lialosia nearly have the common characters to the present one. Lialosia is known from lower to middle Permian of Australia. Heteralosia, an widely distributed Heteralosiin genus with long stratigraphic occurrence from Carboniferous to Permian, also has prong-like teeth. It is, however, probably distinguishable from the present form by having the posteriorly sulcate and anteriorly rounded teeth.

Superfamily Aulostegacea MUIR-WOOD and COOPER, 1960

Family Aulostegidae MUIR-WOOD and COOPER, 1960

Subfamily Echinosteginae MUIR-WOOD and COOPER, 1960

Genus Echinosteges MUIR-WOOD and COOPER, 1960

Type-species.-Aulosteges tuberculatus R.E. KING, 1931

Echinosteges? sp.

Pl. 2, figs. 13, 14

Descriptive remarks. - Two fragmentary moulds of pedicle valve, HSG-(H)020 and HSG-(H)021, are available. The former specimen, the better preserved one, has 
the following dimension; length, ca. $18 \mathrm{~mm}$, width, ca, $22 \mathrm{~mm}$, length of hinge line, 7 $\mathrm{mm}$, height of interarea, $4 \mathrm{~mm}$. Rubber replicas of them well reveal the character of spines. The pedicle valve is rounded trigonal with the posteriorly tapering umbo, slightly convex venter and broadly shallow sulcus. The hinge line is much shorter than the largest width which locates at anterior to the midlength. Narrow elongated and apsacline interarea is confirmed with an obscure elytridium at the top. The surface of pedicle valve is ornamented by fine and densely arranged spines of two series, recumbent and suberect ones. Anteriorly these spines of two series often diverge from the prostrate spine ridge. Postero-laterally the erect spines are often crowded. The halteroid spines are suggested for them. In general the posteriorly tapering,

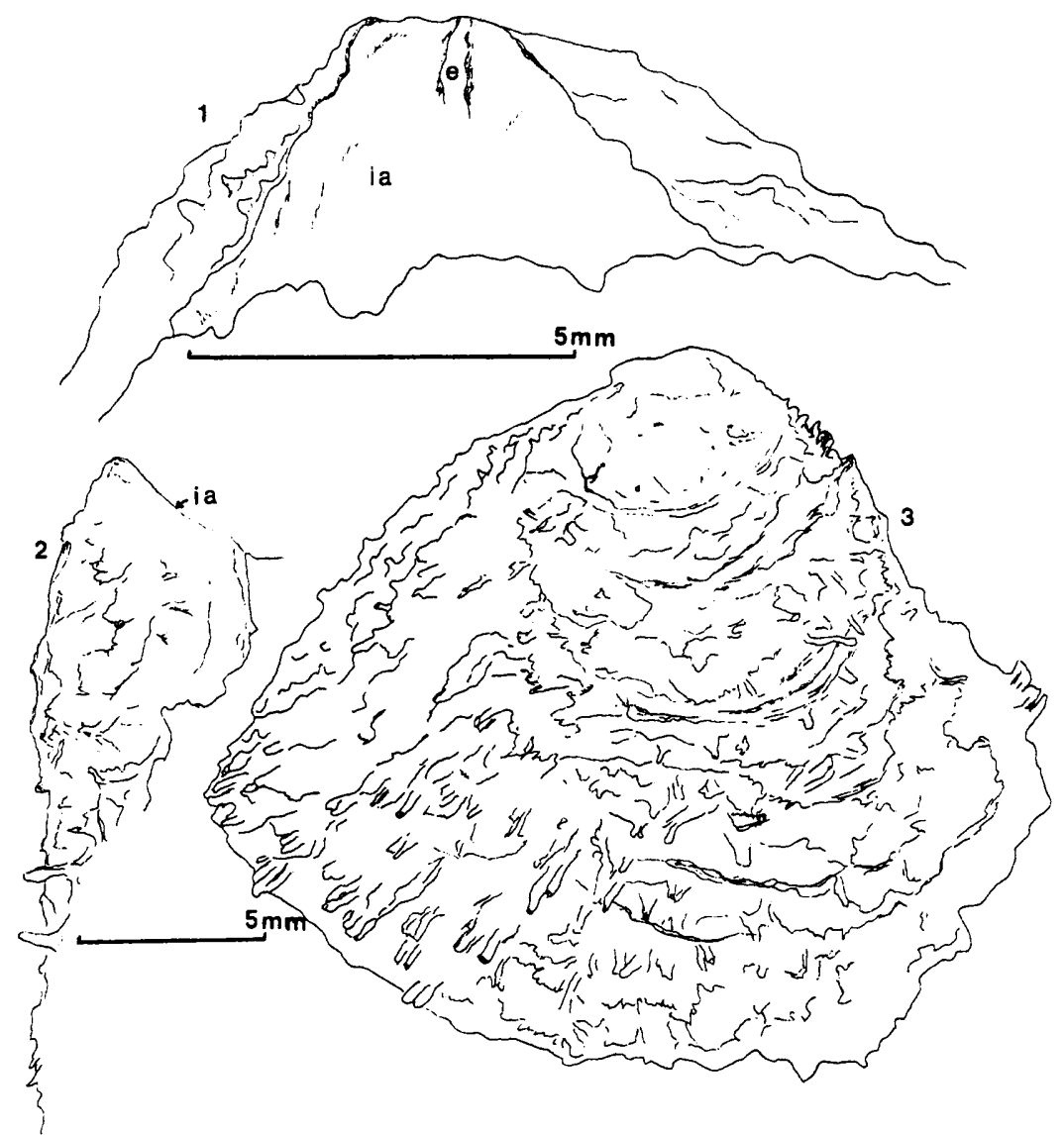

Fig. 7. Echinosteges? sp.

1. Enlarged view of the posterior part of the pedicle valve, showing the interarea and obsolete elytridium.

2. Lateral view showing inclination of the interarea.

3. External ornamentation of the pedicle valve, showing the anteriorly prostrate and suberect, irregular spines and weak growth lines.

e, elytridium; ia, interarea sp. no. HSG-(H)020 
rounded trigonal form, the character of the interarea and spines of the present specimens are well in harmony with those of the Echinosteginae, and Echinosteges is possibly identifinable for the generic position of the present specimens.

Superfamily Rhynchonellacea Gray, 1848

Family Allorhynchidae COOPER and GRANT, 1976

Genus Allorhynchus WELLER, 1910

Type-species.—Rhynchonella heteropsis WINCHELL, 1865

Allorhynchus sp.

Pl. 2, fig. 1

Descriptive remarks.-An incomplete specimen, HSG-(H)022, is available. The internal structure is slightly preserved posteriorly in a mould and partly recognizable by the rubber replica. The shell is small and rounded pentagonal in outline with the following dimensions: length, ca. $6 \mathrm{~mm}$; width, ca. $6 \mathrm{~mm}$; thickness, ca. $3 \mathrm{~mm}$. The anterior commissure is uniplicate with 2 rounded costellae in the sulcus and 3 on the fold at the frontal margin.

The pedicle valve is weakly convex. The beak region is exfoliated but acute and slightly incurved character may be suggested from the outline. The sulcus is shallowly and widely developed on the anterior half. The pedicle valve is ornamented by the simple subrounded costellae, originating near the beak, 2 costellae in the sulcus and 6 to 7 costellae on each lateral slope. The pedicle valve interior is with the very short dental plates. The brachial valve is more inflated than the opposite valve. The broad low fold is recognized on the anterior half of the brachial valve with 3 costellae on it. The lateral slopes are respectively ornamented by about 6 costellae. The brachial valve interior is with the fragmentary hinge plate, not united by the connecting plate.

The present specimen is probably in a young stage of growth. A rubber replica shows the very short dental plates and separated hinge plates, though the shell is more or less broken as it may be fragile. These internal characters along with the

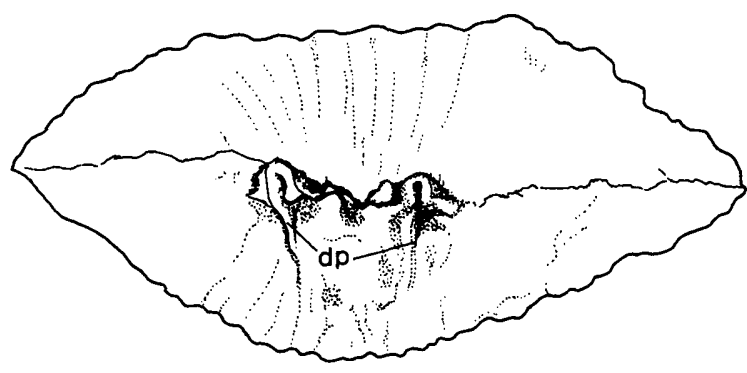

$2.5 \mathrm{~mm}$

Fig. 8. Allorhynchus sp.

Internal view of the posterior margin of a specimen, HSG-(H)022, by a rubber replica, showing articulation of both valves with the dental plates(dp) in the pedicle valve. 
external radial costellae which begin near the beak and are rather numerous for the size of the shell well represent the character of Allorhynchus. In external configuration the present specimen resembles those of Permian species of Terbratuloidea depressa WAAGEN from the Upper Permian Productus Limestone of the Salt Range. The former, however, is distinguished from the latter by having the dental plates. The external costellae of the latter species are angular to the contrary of the former rounded ones. Allorhynchus is usually known in Carboniferous and then this may be the youngest species of Allorhynchus. Externally the similar species were described from some provinces in Permian of the Tethys region. Among the figured specimens by HUANG (1933) under the name of Pugnax pseudutah from the Upper Permian of Changsingian in south China, some specimens resemble the present one. HUANG noted the existence of short subparallel dental plates in the pedicle valve and two thin crural plates just below the hinge margin. The crural plates were not confirmed in the present specimen. However, the general internal characters of the Chinese specimens are similar to our material. The present specimen, however, is completely distinguished from HUANG's specimens in having the larger number of costellae, starting at the beak region. These in south Chinese specimens all originate at a distance slightly anterior to the beak.

LIAO (1980) established a similar species from the Changsingian of western Guizhou, south China, under the name of Neowellerella triplicata. Internal structure shown by LIAO is nearly common to the present specie. The former, however, is externally distinghishable from the latter.

\author{
Superfamily Retziacea WAAGEN, 1883 \\ Family Retziidae WAAGEN, 1883 \\ Genus Hustedia HALL and ClARKE, 1893 \\ Type-species._Terebratula mormoni MARCOU, 1858 \\ Hustedia sp.
}

Pl. 1, fig. 1

Descriptive remarks.-A small incomplete external mould of brachial valve, HSG-(H)023, with rounded globular outline and the following dimension is available: length, $8.5 \mathrm{~mm}$; width, ca. $8 \mathrm{~mm}$.

The shell surface is ornamented by the rounded simple costae, median costa and 5 lateral costae on each side of the median costa. The lateral costae originate at the beak, and the median costa, however, originates at a distance from the beak. Furrows between the costae anteriorly become broader and flatter. The median septum is posteriorly shortly observable.

The present specimen is small and the following external characters, such as the semiglobular outline and rounded costae with a median costa, originating at slightly anterior to the beak, are remarkable. Taking these characters into consideration the present specimen recalls those of Middle Permian Hustedia ratburiensis GRANT, 1976, from Ko Muk, southern Thailand. Externally the brachial valve of $H$. ratburiensis is in harmony with the present species, though the former occurs stratigraphically lower than the latter. SHIMIZU (1961) described Hustedia grandicos$t a$ (DAVIDSON) and $H$. indica from the Permian Maizuru Group in the Kawahigashi 
and Yakuno districts. Among the figured specimens by SHIMIZU an internal mould of a brachial valve (Pl. 16, fig. 42) of Hustedia grandicosta resembles the present specimen in character of the median costa. The Maizuru specimen, however, has the fewer number of costae than the present one.

Superfamily Spiriferacea KING, 1846

Family Brachythyrididae FrEDERICKS, 1924

Genus Spiriferella TsCHERNYSCHEW, 1902

Type-species.-Spirifer saranae VERNEUIL, 1845

Spiriferella sp.

Pl. 1, fig. 2

Descriptive remarks._An incomplete, small pedicle valve, HSG-(H)024, with length, ca. $24 \mathrm{~mm}$ and width, ca. $25 \mathrm{~mm}$, is available. The external surface of the valve is slightly exfoliated and then the complete outline is not recognizable. The shell is small for the genus, convex, presumably transversely rounded in outline, and posteriorly very thick. The surface of the valve is ornamented by broadly rounded costae, 5 costae on each lateral surface. The sulcus is broad and shallow with the flattened bottom, and accompanied by 3 or 4 narrow, low and rounded weak plications. The intercostal furrows round-bottomed with nearly same width to the neighbouring costae in the anterior half. The costae laterally rapidly decrease strength.

The present specimen is characterized by broadly rounded, anteriorly rarely bifurcating costae, broad shallow sulcus with low plications on bottom and the lateral slopes, and the broad intercostal furrows are rounded in the bottom.

Among the known Permian species of Spiriferella, lower Permian Spiriferella salteri TSCHERNYSCHEW (1902) from the Schwagerina limestone of Ural and Timan has the similar character on the external ornamentation to the present species. The same species from the Middle Permian of the Jisu Honguer Limestone, Mongolia (GRABAU, 1931) is also externally similar to the present species. The former, however, is probably distinguished from the latter by having the broader costae and presumably wider outline than the latter.

Superfamily Spriferinacea Dvidson, 1884

Family Reticulariinidae COOPER and GRANT, 1976

Genus Spiriferellina FREDERICKS, 1924

Type-species.-Terebratulites cristatus SchlothEIM, 1816

Spiriferellina sp.

Pl. 1, figs. 3-5

Descriptive remarks.-Three fragmentary external moulds of pedicle valve, HSG-(H)025, 026 and 027, are available. They are small for the genus. Though they are incomplete, their outlines are suggested to be not so laterally extended. The sulcus is conspicuously developed with broad and flattened bottom. The surface is covered by 4 to 5 or 6 subrounded simple costae on each side of the sulcus. The lateral 
costae originate at the beak but rapidly decrease their strength laterally. Intercostal furrows are subangular and narrower than the width of the adjoining costae. Traces of punctae are recognizable by numerous minute granules on the surface. Among three specimens a transverse one (Pl. 1, fig. 4) seems to have the larger number of costae than others. Other two specimens have the larger sulcus-bounding costae than the former one. Spiriferellina orientalis (FRECH) from the Upper Permian of south China resembles the present species in external characters.

\section{Remarks on the brachiopod fauna of the Karita Formation}

The elements of the brachiopod fauna of the Karita Formation have some noticeable alliances particularly within those of the Upper Permian of the Maizuru Group in the Maizuru zone, Southwest Japan and those of the Upper Permian Lontangian Stage in south China.

Of elements of the Maizuru brachiopod fauna Neochonetes substrophomenoides and Derbyia altestriata from the upper part of the Upper Formation of the Maizuru Group in the Kawahigashi area are common to the Karita fauna. The former species is particularly abundant in occurrence in both faunas. Hustedia sp. in the Karita fauna is closely related to $H$. grandicosta in the external characters. Neochonetes substrophomenoides and Derbyia altestriata are origninally described by HUANG (1932) from the Upper Permian Lyttonia bed in Guizhou, south China and by WAAGEN (1882) from the Upper Productus Limestone in the Salt Range, Pakistan, respectively.

Outside of Japan the Karita fauna is strongly related to the Upper Permian brachiopod fauna in western Guizhou, south China, which was biostratigraphically examined and many new species were described by LIAO (1980). Among elements of the Karita fauna an important species is Oldhamina anshunensis. This species shows a wide geographic distribution and restricted stratigraphic occurrence not only in south China but also in eastern and northwestern China, such as Anhui, Hunan and Shansi, respectively. LIAO (1980) remarked that $O$. anshunensis is remarkable in occurrence in the Upper Permian Lontangian Stage in south China, though it ranges up to the Changsingian Stage.

Of the Upper Permian brachiopods from the Toyoma Formation in the Kitakami Mountains, Northeast Japan, Oldhamina kitakamiensis TAZAWA was compared by the author (1982) with O. anshunensis. Leptodus sp. of the Karita Formation is closely related to both $L$. richthofeni KAYSER and $L$. nobilis (WAAGEN), originally from the Upper Permian of the Loping province, south China, and from middle and upper Productus limestone in the Salt Range, respectively. In south China L. nobilis is characteristic in the Lontangian and Chansingian Stages. It is also the common species of the Upper permian in the Tethyan province. Derbyia sp. of the Karita Formation is externally very close to both $D$. acutangula and $D$. mucronata. The latter species are the representative ones of the Lontangian Stage and characteristic in having the trapezoidal outline with extended hinge. Neochonetes substrophomenoides is common both in the Lontangian and Changsingian Stages in south China. 


\section{Conclusion}

The brachiopod fauna of the Karita Formation comprises close alliances with that of the Upper Formation of the Permian Maizuru Group in the Maizuru zone, Southwest Japan. Outside of Japan the Karita fauna is closely related to the Upper Permian Lontangian and Changsingian brachiopod faunas in south China. Especially the Karita fauna is highly comparable with the lower Upper Permian Lontangian brachiopod fauna. The elements of the Karita faunna are characteristically composed of those of the Tethyan province, though they rarely comprize such an element known in the boreal water as Spiriferella.

SHIMIZU (1961) noted on the Karita brachiopod fauna by IMAMURA (1953) in his discussion of the Maizuru fauna that the Leptodus-bearing limestone of the Karita Formation is correlative to the middle part of the Maizuru Group. Specimens identified as Leptodus ricthofeni by IMAMURA are now referable to belong to Oldhamina anshunensis and Leptodus sp. The latter is closely related with $L$. richthofeni and also $L$. nobilis. The former species is very common in the lower Upper Permian Lontangian in south China and is often accompanied by Neochonetes substrophomenoides.

The Lontangian yields abundant fusulinaceans. Of them some species of Codonofusiella are characteristic in occurrence. Besides Codonofusiella, Reichelina, Sphaerulina and Nankinella commonly associate and they compose the Codonofusiella Zone.

It is well recognizable in the Karita Formation that a limestone lens (loc. 6) beneath the brachiopod-bearing calcareous sandstone of the Member $d$ includes abundant foraminifers such as Colaniella cf. minima WANG, Codonofusiella sp. and Reichelina sp. (OKIMURA and SADA, in HASE and AIBA, 1977). Palaeofusulina has not been discriminated from the Member $d$ of the Karita Formation. In south China Palaeofusulina stratigraphically first appears in the lower Changsingian (SHENG, 1963). These fusuline occurrence both in the Lontangian and the Karita Formation and the deduced early Late Permian age of them are well in harmony with that concluded from the brachiopod faunas of both formations.

\section{References}

FENG, R. and JIANG, Z. (1978): Brachiopoda in Fossil atlas of southwest province, Guizhou part 2. 231-305, pls. 85-108, Science Press, Beijin (in Chinese).

Frech, F. (1911): Die Dyas, in Richthofen, F. von; China. 5, 103-202, pls. 19-28, D. Reimer (Berlin).

Grant, R.E. (1976): Permian brachiopods from southern Thailand. Jour. Paleont., Supplement, 50, (3), 1-269, pls. 1-71.

HASE, A. (1964): Paleozoic formations in Hiroshima Prefecture in explanatory text of geological map of Hiroshima Prefecture. 31-59, pls. 1, 2, Hiroshima Prefecture (in Japanese).

HASE, A. and AIBA, M. (1977): Stratigraphy of the Permian Karita Formation in the environs of Hiroshima, Japan: with palaeontological description of foraminifers by OKIMURA, Y. and SADA, K. Jour. Sci., Hiroshima Univ., [C], 7, (4), 203-216, pl. 1.

Huang, T. (1932): Late Permian brachiopods of southwest China. Palaeont. Sinica, [B], 9, (1), 1-138, pls. 1-9. 
(1993): Late Permian brachiopods of southwest China, Part II. Ibid., [B], 9, (2), 1-131, pls. $1-11$.

IshiI, K., OKimura, Y. and NaKazawa, K. (1975): On the genus Colaniella and its biostratigraphic significance. Jour. Geosci., Osaka City Univ., 19, (6), 107-129, pls. 1-4.

LIAO, Z. (1980): Upper Permian brachiopods from western Guizhou in Stratigraphy and palaeontology of Upper Permian coal-bearing formation in western Guizhou and Yunnan. 241-277, pls. 1-9, Sci. Press, Beijing (in Chinese).

LIU, Z., TAN, Z. and DING, Y. (1982): Brachiopoda in The palaeontological atlas of Hunan, 172-216, pls. 125-159, Geological Publishing House, Beijing (in Chinese).

Sheng, J. (1963): Permian fusulinids of Kwansi, Kueichou and Szechuan. Palaeont. Sinica, [N.S.], (10), 1-247, pls. 1-35 (in Chinese and English).

Shimizu, D. (1961): Brachiopod fossils from the Permian Maizuru Group. Mem. Coll. Sci., Univ. Kyoto, [B], 27, (3), 309-350, pls. 15-18.

- (1962): The Permian Maizuru Group, its stratigraphy and syntectonic faunal succession through the latest Paleozoic orogeny. Ibid., [B], 28, (4), 571-609.

TAZAwA, J. (1982): Oldhamina from the Upper Permian of the Kitakami Mountains, Japan and its Tethyan province distribution. Trans. Proc. Palaeont. Soc. Japan, N.S., (128), $445-451$, pl. 69.

TSCHERnYsCHEW, T.N. (1902): Die obercarbonischen Brachiopoden des Ural und des Timan. Mem. Com. Geol. St. Petersburg, 16, (2), 1-749, pls. 1-63.

WAAGEN, W.H. (1882-1885): Salt Range fossils, part 4: (2) Brachiopoda. Palaeont. Indica, [13], $329-770$, pls. $25-86$.

Wang, K., Ching, C., Jin, Y., Hu, S., Liang, W. and LiaO, Z. (1982): Brachiopoda in Palaeontological atlas of east China, Part 2, Volume of Late Paleozoic. 186-256, pls. 74-102, Geological Publishing House, Beijing (in Chinese).

Zhan, Y., Ful, L., Ding, P. and QI, W. (1983): Brachiopoda in Paleontological atlas of northwest China, Shaanxi, Gansu and Ningxia Volume, Part 2, Upper Paleozoic. 244-425, pls. 88-143, Geological Publishing House, Beijing (in Chinese). 